Editorial

\title{
Why Choice Matters: Revisiting and Comparing Measures of Democracy
}

\author{
Heiko Giebler ${ }^{1, *}$, Saskia P. Ruth ${ }^{2}$ and Dag Tanneberg ${ }^{3}$ \\ ${ }^{1}$ Research Unit 'Democracy \& Democratization', WZB Berlin Social Science Center, 10785 Berlin, Germany; \\ E-Mail: heiko.giebler@wzb.eu \\ 2 Institute of Latin American Studies, German Institute of Global and Area Studies, 20354 Hamburg, Germany; E-Mail: \\ saskia.ruth@giga-hamburg.de \\ ${ }^{3}$ Chair of Comparative Politics, University of Potsdam, 14482 Potsdam, Germany; E-Mail: dag.tanneberg@uni-potsdam.de \\ * Corresponding author
}

Submitted: 19 February 2018 | Published: 19 March 2018

\begin{abstract}
Measures of democracy are in high demand. Scientific and public audiences use them to describe political realities and to substantiate causal claims about those realities. This introduction to the thematic issue reviews the history of democracy measurement since the 1950s. It identifies four development phases of the field, which are characterized by three recurrent topics of debate: (1) what is democracy, (2) what is a good measure of democracy, and (3) do our measurements of democracy register real-world developments? As the answers to those questions have been changing over time, the field of democracy measurement has adapted and reached higher levels of theoretical and methodological sophistication. In effect, the challenges facing contemporary social scientists are not only limited to the challenge of constructing a sound index of democracy. Today, they also need a profound understanding of the differences between various measures of democracy and their implications for empirical applications. The introduction outlines how the contributions to this thematic issue help scholars cope with the recurrent issues of conceptualization, measurement, and application, and concludes by identifying avenues for future research.
\end{abstract}

\section{Keywords}

application; conceptualization; democracy; democratic quality; measurement

\section{Issue}

This editorial is part of the issue "Why Choice Matters: Revisiting and Comparing Measures of Democracy", edited by Heiko Giebler (WZB Berlin Social Science Center, Germany), Saskia P. Ruth (German Institute of Global and Area Studies, Germany), and Dag Tanneberg (University of Potsdam, Germany).

(C) 2018 by the authors; licensee Cogitatio (Lisbon, Portugal). This article is licensed under a Creative Commons Attribution 4.0 International License (CC BY).

\section{Introduction}

Over the past decades, the field of democracy measurement has grown tremendously. The continuous scientific and public demand for measures of democracy has generated an unprecedented wealth of measurement instruments aiming to capture democracy. Yet, having reviewed the development of the field since the 1960s, Bollen (1991, p. 4) found scant evidence for a "smooth evolution towards clear theoretical definitions and finely calibrated instruments". One decade later, Munck and Verkuilen (2002, p. 28) still concluded that "no single index offers a satisfactory response to all three challenges of conceptualization, measurement, and aggregation". But certainly, all is not lost for measuring democracy. Rather, scholars have incorporated much of the critique, which resulted in major improvements. As a result, social sciences today enjoy a vast supply of high-quality approaches to measuring democracy. Now, the challenge is not so much to select a sound index of democracy but rather to understand the theoretical and methodological differences between various indices as well as the consequences of their application. Nevertheless, several recurring topics and issues in the literature on democracy measurement clearly indicate there is still the need for further improvement. 
This thematic issue focuses mainly on three aspects to improve research on democracy measurement and research using measures of democracy: (1) Conceptualization: what do differences in theoretical grounding and conceptualization of democracy measures mean for empirical analyses? While some measures follow a minimalistic definition of democracy, others go as far as including political outcomes. Moreover, the conceptual differences between graded measures of democracy are seldom in the focus of research. However, they can be quite substantial. Which measures can and should be used for which substantive research questions? (2) Measurement: much of the debate on measuring democracy revolves around the nature and scaling of appropriate indicators. Do observables make better or merely different data? Conversely, do expert judgments or public opinion data achieve higher validity or are they just biased in different ways? At the same time, existing measures of democracy differ tremendously in their aggregation rules. What substantive differences do those alternatives imply? (3) Application: finally, in terms of real-world developments and resulting research questions, how are the conceptualization and nature of a democracy measure related to its applicability? In line with the contributions to this thematic issue, we argue that the relevance of this question goes far beyond a two-measure comparison in the field of democratization. New measures allow us to address new questions, to revise the answers to old questions, to delve deeper into the realm of causal mechanisms, and, last but not least, more valid application in general. In sum, it seems reasonable to revisit and compare measures of democracy from different perspectives despite all the positive developments in the field.

This editorial serves both as an introduction to and as a summary of the thematic issue. First, we provide a short summary of several development phases in the history of democracy measurement. We show that these developments can be traced back to very similar motives and origins. We then outline why and to which regard there still is the necessity for improvement in the field of democracy measurement. Finally, we discuss how this thematic issue addresses some of the existing problems by presenting the main findings of all nine contributions in the broader context of future avenues for democracy measurement.

\section{A Brief History of Democracy Measurement: Improvements, Recurring Topics, and Persistent Shortcomings}

In a way, democracy measurement is a prime example of empirical research in political science. The following brief history of the field, which spans more than six decades, demonstrates that scholars adapted democracy measurement in response to major political events or changes in the nature and distribution of political regimes. Whenever existing measures fell out of touch with real-world developments or new substantively important questions arose, democracy measurement was quickly responding. At the same time, democracy measurement remained in close contact with developments in the discipline itself, particularly to democratic theory and political methodology. Three questions drive the development of democracy measurement: (1) what is an appropriate definition of democracy, (2) what does an appropriate measurement of that definition look like, and (3) are the measures applicable to real-world phenomena?

Clearly, there are significant problems regarding research on democracy measurement. As is often the case in the social sciences, it is hardly possible to reach consensus in terms of conceptualization or measurement. 20 years later it is still worth quoting Vanhanen's (1997, p. 31) assessment of democracy measurement in full: "It has been much more difficult to find suitable measures of democracy and to measure the variation in the level of democracy than to formulate a definition of democracy. In fact, nearly all researchers who have attempted to measure democracy have used different indicators. The situation is confusing". Vanhanen describes a very important problem that has yet to be solved. There have been important advancements but we also observe recurring topics and problems in all historical phases of democracy measurement. We count four major phases of development that will be presented in the following with a special focus on the applicability of measures, conceptualization of democracy, and adequacy of measurement. ${ }^{1}$

Phase 1: Modernization Theory and Democracy. Efforts to measure democracy stretch back to the 1950s and 1960s. Following the horrors of World War II and the preceding crisis of democracy in many countries, scholars pondered on the relationship between democracy and modernization. In the course of the debate, Lipset's (1959) "Some Social Requisites of Democracy" advanced as a theoretical and empirical model for numerous future studies. Lipset's seminal piece was not just the first to explicate the link between economic development and democracy (Wucherpfennig \& Deutsch, 2009, p. 1), it also translated Dahl's (1956) procedural conception of democracy into a term fit for empirical investigation. In Lipset's words, democracy "is a social mechanism for the resolution of societal decision making among conflicting interest groups" that permits the participation of the largest possible share of the population (Lipset, 1959, p. 71). The questions intriguing Lipset and many others (e.g., Adelman \& Morris, 1971; Coleman, 1960; Cutright, 1963; Cutright \& Wiley, 1969; R. W. Jackman, 1973; Johnson, 1976; Neubauer, 1967; Smith, 1969) was how to achieve stable democracy and how to recognize it.

An occasionally vicious debate over parsimonious and not so parsimonious conceptions of democracy en-

\footnotetext{
${ }^{1}$ Obviously, it is impossible to provide a complete summary of all different approaches to democracy measurement published since the 1950 s. However, the development and nature of all measures follow certain time-specific patterns, which allows us to provide a comprehensive overview neverthelessalbeit on a more abstract level and focusing on the most relevant measures and scholars.
} 
sued, a debate which has continued until today (e.g., Coppedge et al., 2011; Held, 2010; Przeworski, 1999; Schmitter \& Karl, 1991). According to Lipset, in the 1950s, stable European democracies had provided uninterrupted rule since World War I and had not met any major domestic anti-democratic movement in the previous 25 years (Lipset, 1959, p. 73). He followed these criteria to separate "stable democracies" from "unstable democracies and dictatorships" (Lipset, 1959, p. 74). Scholars objected to Lipset's admittedly crude dichotomy for various reasons. On the one hand, they criticized his binary classification, which disregarded gradual differences between democracies (e.g., Cutright, 1963). On the other hand, scholars added new properties to the concept of democracy, including aspects of the constitutional state, party competition, as well as the participation (Neubauer, 1967) and representation of citizens (Cutright \& Wiley, 1969; Lauth, Pickel, \& Welzel, 2000, p. 11). Thus, strictly procedural conceptions of political democracy (Dahl, 1971; Downs, 1957; Schumpeter, 1950) clashed with more universal, social conceptions of democracy which went well beyond the properties of political competition (Bollen, 1991).

Early attempts to measure democracy featured problems of theory, methodology, and applicability. Concepts often did not adequately distinguish between the properties of democracy and its consequences. Moreover, conceptual attributes and indicators of democracy were occasionally only loosely connected. Finally, the resultant indices rarely covered more than a handful of countries or years and were often selected on the basis of data availability rather than substantive criteria. Those deficits in measuring democracy resulted in a barrage of contradictory findings on fundamentally important questions such as the connection between the levels of political democracy and economic inequality (Bollen, 1980).

Phase 2: Differentiation and Sophistication. During the late 1970s and the 1980s, applications of democracy measurements spread to new research areas, e.g., political economy and international relations. More importantly, those years constitute a first blooming of truly comparative measurements of democracy. Many of the most influential measurements of democracy emerged during that period. Freedom House's report on Freedom in the World began its annual circulation in 1978. Although never intended to meet the standards of scientific research (Gastil, 1991, p. 21), its civil liberties and political rights scales found their way into countless scientific applications. In 1975, the first version of the Polity data was used to study patterns of political authority (Gurr Jaggers, \& Moore, 1991, p. 73). Interestingly, measuring democracy was not their primary intent, as Polity's famous 21-point scale aggregates patterns of authority related to either autocracy or democracy (Gurr, et al., 1991, p. 79). Vanhanen's (1971) index of democratization, in contrast, directly measured competition and participation in elections, recognizing them as necessary features of democracy (Vanhanen, 2000, p. 256).
Finally, Bollen (1980) presented his Political Democracy Index and his extensive use of structural equation models (SEMs) changed the methodological standard in measuring democracy.

SEMs and related approaches use path diagrams to communicate the structure of terms and even entire theories. Path diagrams might be seen as a minor byproduct of a highly specific approach to empirical analysis, but that does not diminish the fact that they made democracy measurement more rigorous. More importantly, Bollen's work reinforced the move towards graded scales in measuring democracy. His analyses built on the firm convictions that (1) democracy is a matter of degree and (2) that dichotomous or even trichotomous measurements of democracy (e.g., Gasiorowski, 1990) introduce substantial measurement errors into the analysis (Bollen, 1991, p. 14; S. Jackman, 2008). Bollen was clearly not the first to advocate degrees of democracy. However, his rigorous assessments of measurement transparency, reliability, and validity justified the use of graded scales in the shadow of a fierce controversy over the proper order of classification and quantification in the social sciences (Sartori, 1970). In short, during this phase best practices emerged in the field. Those prepared the ground for some very important features of modern democracy measurement, e.g., concept trees, theory-consistent aggregation rules (Munck \& Verkuilen, 2002), and the conscious choice of data types and sources (Bollen, 1991).

Phase 3: The Age of Hybridization. When the Cold War ended in the early 1990s and Huntington's (1991) "third wave" of democratization surged, the measurement of democracy faced new challenges. On one hand, the number of political systems that were at least minimally democratic had grown substantially. This international spread of democracy also underlined the need for more precise measurements (Lauth et al., 2000, p. 8). On the other hand, democracy indices were criticized for their alleged Western bias. The debate pitted cultural universalism against relativism (Sowell, 1994) and forced existing indices to justify why their conception of democracy should apply across time and space. As more crossnational survey data became available, new opportunities for measuring democracy arose. Hitherto, democracy indices had either privileged factual, easily observable properties of democracy, or had relied on expert knowledge. Now, it became possible to exploit citizen perceptions of democracy for cross-national empirical research and even policy advice.

Severe theoretical and methodological critiques of existing measures of democracy were one of the first types of response to those three developments. Nothing exemplifies them better than the ACLP dataset (Alvarez, Cheibub, Limongi, \& Przeworski, 1996; Cheibub, Gandhi, \& Vreeland, 2010; Przeworski, Alvarez, Cheibub, \& Limongi, 2000). Its binary distinction between democracy and dictatorship excelled with its theoretical clarity and methodological rigor, proving that the debate between discrete and graded measurements of democracy 
was far from over. In fact, exchanges between the opponents and proponents of classificatory measurement schemes continued well into the new millennium (Bogaards, 2012; Cheibub, et al., 2010; Collier \& Adcock, 1999; Elkins, 2000; Mainwaring, Brinks, \& Pérez-Liñán, 2001). Moreover, in the course of the 1990s and early 2000s, Bollen and Paxton repeatedly discussed pitfalls in measuring democracy. They provided evidence for low validity and method factors in important, subjective measures of democracy (Bollen, 1993; Bollen \& Paxton, 1998, 2000). Others scrutinized the dimensionality and precision of the Polity data (Gleditsch \& Ward, 1997), elaborated on how differences between measurements of democracy resulted in divergent empirical findings (Casper \& Tufis, 2003), or developed frameworks for the systematic comparison of measures of democracy (Munck \& Verkuilen, 2002). Each of these responses highlight the continuing search for the necessary and theoretically proper degree of precision in measuring democracy.

Citizen evaluations entered the field from two different directions. First, scholars used cross-national surveys to study and compare citizen evaluations of democracy. Those contributions walked the line between measuring democracy and studying political culture. For instance, Welzel, Inglehart and Kligemann (2003) and later on Inglehart and Welzel (2005) used the World Values Survey (WVS) to link macro-level modernization to individuallevel aspirations for democracy. Similar connections were later made by Ferrín and Kriesi (2016) who used European Social Survey (ESS) data and thereby demonstrated the ongoing relevance of this research. However, as survey research must rely on standardized questionnaires, those data are not the most granular. Enter the democratic audit, which "constitutes the simple but ambitious project of assessing the state of democracy in a single country" (Beetham, 1994, p. 26). Whereas other measures aim to compare levels of democracy over space and time, the democratic audit proposes a framework for evaluating the living experience of citizens with a democracy. It is every bit as much an analytical as a political tool to empower citizens and it has been used in over 25 countries (Landman, 2012). In retrospect, the audit's success foreshadowed a fundamental shift from measuring the level of democracy to measuring its quality.

Phase 4: Quality, Varieties, and Rollback of Democracy. By the early 2000s, scholars moved away from measuring the level of democracy and had begun to take more interest in its quality (see Altman \& PérezLiñán, 2002; Diamond \& Morlino, 2005; Pharr \& Putnam, 2000). Two observations caused this shift. On one hand, the third wave of democratization left many political regimes stuck in the murky middle ground between democracy and autocracy where multiparty political competition coexists with severe deficits in democratic government. On the other hand, extant measurements rewarded many if not all established democracies with the highest marks, glossing over what struck many as decisive differences. Yet, what is a "good" democracy? Answering that question required newer, broader, mid to wide-range concepts of democracy (e.g., Beetham, 2004; Held, 2010; Merkel, 2004) as well as new data (e.g., Bühlmann, Merkel, Müller, \& Weßels, 2012; Coppedge et al., 2011; Lauth, 2015). However, the empirical domain of the quality of democracy remains contested (e.g., Lijphart, 1999; cf. Munck, 2016) as do the attributes of democracy which impact its quality (e.g., Diamond \& Morlino, 2005; cf. Lauth, 2011) and the way they matter (e.g., Bochsler \& Kriesi, 2013; cf. Giebler \& Merkel, 2016). Mirroring the earlier development of the field, the quality of democracy has inspired much conceptual innovation, but no consensus at all (see Fishman, 2016).

While the "value-laden and hence controversial" (Diamond \& Morlino, 2005, p. iv) quality of democracy has spawned a rich debate, other scholars have refocused methodological aspects of democracy measurement (see Giebler, 2012) and also types of democracy. Echoing Bollen and Paxton, a series of publications demonstrated the utility of latent variable models for reducing measurement error (Treier \& Jackman, 2008), probing dimensionality (Armstrong, 2009), and enhancing validity in democracy measurement (Pemstein, Meserve, \& Melton, 2010). Those contributions differ tremendously in their methodological specifics and intent, but they fundamentally agree that extant measures of democracy "capture similar, but often distinct, aspects of what makes states more or less democratic" (Pemstein et al., 2010, p. 427). In other words, extant measures constitute variations on a single theme. The work on varieties of democracy debates that point, arguing that the numerous configurations of institutions and practices can be reduced to a few distinct patterns of democracy. Lijphart's (1999) distinction between majoritarian and consensus democracy constitutes what is probably the best-known example of that debate. Yet, the Varieties of Democracy project has gone much further, outlining and measuring electoral, liberal, majoritarian, participatory, deliberative, and egalitarian conceptions of democracy (Coppedge et al., 2011).

The moment Huntington coined his maritime vocabulary, he warned of a "two-step-forward, one-stepbackward" (Huntington, 1991, p. 25) dynamic. All past waves of democratization had been followed by a relapse to authoritarianism and it remained to be seen how persistent the results of the third wave would be. Soon Puddington (2008) titled "Freedom in Retreat: Is the Tide Turning?" and Diamond (2008) announced "The Democratic Rollback", such that other scholars promptly began to ask "Are Dictatorships Returning?" (Merkel, 2010). The answer depends very much on the democracy index used. For Freedom House, which declared an outright crisis of democracy after twelve consecutive years of decline (Abramowitz, 2018, p. 1), the case is blatantly clear. Comparing data provided by Freedom House, Polity IV, the Economist Intelligence Unit, and the Bertelsmann Transformation Index, Levitsky and Way (2015), however, 
found scant evidence for a global retreat of democracy between 2000 and 2013. In contrast, based on the latest Varieties of Democracy data, Mechkova, Lührmann and Lindberg $(2017$, p. 162) produced evidence for a moderate rollback "with democracies becoming less liberal and autocracies less competitive and more repressive". The debate on the rollback of democracy rages on and the field of democracy measurement has effectively come full circle: Once again, scholars are asking what stable democracy looks like.

\section{Lessons Learnt? Locating This Thematic Issue in the Debate}

Again, the three big questions of the field boil down to matters of conceptualization, measurement, and application. What is democracy? What is a good measure of democracy? Finally, do our measurements of democracy reflect real-world political developments? For decades, scholars have pitted different conceptions of democracy against each other (e.g., Alvarez, et al., 1996; Bollen \& Jackman, 1989; Collier \& Adcock, 1999) and they have quarreled over the translation of theoretical terms into observational concepts (e.g., Munck \& Verkuilen, 2002; Pickel, Stark, \& Breustedt, 2015). Disagreement continues and, ultimately, measures of democracy have to prove their value by registering real-world developments. As more sophisticated answers to each of those questions have become available, more practical wisdom is required in order to exploit the full potential of contemporary measures of democracy. Hence, it is time to revisit and compare measures of democracy to show that measurement choice actually matters.

In that regard, prior publications on democracy measurement leave something to be desired. For instance, many of the democracy indices introduced and discussed in the chapters of Inkeles' (1991) ground-breaking edited volume have been abandoned. Although the book still offers an instructive read, it provides limited orientation on contemporary democracy measurement. Later contributions such as the now classic review by Munck and Verkuilen (2002) and Munck's (2009) book-long treatment of the topic provide invaluable, comparative assessments of select democracy indices. However, they do not demonstrate in great detail how or why those differences affect empirical research nor do they provide much methodological advice on democracy measurement beyond concept building. Later review articles such as Pickel et al. (2015) often emphasize measuring the quality of democracy as does a recent thematic issue edited by Geißel, Kneuer and Lauth (2016). Moreover, the latter explicitly refrains from supplementing the methodological debate that accompanies measuring democracy since the inception of the field (Geißel et al., 2016, p. 572). However, "theoretical and methodological concerns must go hand-in-hand" (Blalock, 1982, p. 9), and it is the stated intent of this thematic issue to provide practical wisdom on both.
Regarding the conceptualization of democracy, Dahl's (1971) concept of polyarchy has held the field together in the past. Virtually every measure of democracy pays respect to its twin dimensions of contestation and participation (Coppedge, Alvarez, \& Maldonado, 2008). However, there is a vast number of conceptualization approaches that go beyond Dahl's minimalistic and institution-centered approach (Shapiro, 2003). Moreover, if societies and challenges to democracy change, democracy itself may do so as well, requiring modifications to existing conceptualizations of democracy. Several contributions to this thematic issue tackle that challenge head-on. Fleuß, Helbig and Schaal (2018) show the need for careful theoretical reflection and conceptualization to integrate the demanding concept of democratic deliberation, for which systematic measures exist mainly on the micro and meso level, into democratic performance measures at the macro-level. They highlight that there may not be a one-size-fits-all solution to measures of democratic deliberation and propose a modular approach that builds on different parameters to capture democratic deliberation on the macro level. Their contribution can be considered as a roadmap for future researchers aiming at measuring democratic deliberation at the system level.

Echoing developments in the fourth phase of democracy measurement highlighted above, the contribution by Fuchs and Roller (2018) argues that the quality of democracy is based both on objective (institutional as well as procedural characteristics) and subjective criteria (public opinion). Hence, they translate different normative models of democracy to the level of public opinion data and measure their acceptance in different countries all over the world. While this does not contest the various models in terms of their conceptualization it does indeed challenge any institutional or formal approach to democracy measurement. In a similar way, Mayne and Geißel (2018) turn their attention to the crucial role of citizens in democratic quality assessments. Aiming to identify what constitutes a "good" citizen they conceptualize and discuss potential measures of three citizen dispositions that make up the citizen component of democratic quality "breathing life" into democratic institutions. Moreover, Mayne and Geißel (2018) raise awareness of the fact that different institutional models of democracy consider different types of citizen (i.e., different dispositions) as being "good" (or bad) for democratic quality.

Landman (2018) turns to another important point of debate, asking to what degree democracy and human rights overlap. Recent contributions claim inextricable theoretical and empirical connections between democracy and human rights (Hill, 2016; Hill \& Jones, 2014). Landman, in contrast, demonstrates that those connections are variable and depend systematically on the conception of democracy employed. In a related effort, Lührmann, Tannenberg and Lindberg (2018) revisit the debate on degrees of democracy and types of political regimes. Their contribution underlines the importance 
of a conceptually sound distinction between closed and electoral autocracies on one hand and electoral and liberal democracies on the other hand. Based on the latest V-Dem data, the article also serves as an interesting proof of concept: Classification and quantification can go hand in hand if the underlying data receive careful attention.

In fact, democracy measurement requires as much careful attention as conceptualization. Although the field has accumulated much methodological wisdom over the years, several lacunae remain. The contribution of Lauth and Schlenkrich (2018) presents an approach to tackle the long-standing question of whether there is a trade-off between certain democratic principles-first and foremost whether both freedom and equality can be maximized in a democracy. In doing so, it allows for a more valid operationalization of various democratic models without demanding a normative decision on which model constitutes the best model of democracy. Elff and Ziaja (2018) carry on the work of Bollen and others. The authors use confirmatory factor analysis to gauge potentially biasing method factors in four high profile measures of democracy. Their results serve as a sobering reminder not to take measures of democracy at face value. As the authors show, apparent differences between or trends within countries may be more telling about the measurement instrument itself than about real-world developments.

Skaaning's (2018) discussion of different types of data sources makes a similar point. Premised on the assumption that observational features of political regimes have as many drawbacks as in-house coding and expert or population surveys, Skaaning reflects on the numerous trade-offs involved in measuring democracy reliably and validly. The article carefully considers each type of data and formulates numerous best-practices for the production and application of democracy data. Even though scholars have developed several measures that are able to detect differences even in established democracies, Fuchs and Roller (2018) show that the variation might still be underestimated if public opinion data on democratic quality is not taken into account. Hence, they link the debate on data types to the debate on more hybrid manifestations of democracy.

In terms of application, finally, the thematic issue showcases efforts to explain divergent empirical findings by theoretical and methodological differences between extant measures of democracy and it provides guidance on best practices. The article by Escher and Walter-Rogg (2018) constitutes a mixture of replication and genuine research. It sheds light on the question of whether democracy is good or bad for climate protection. In contrast to earlier approaches, the article makes use of the multi-level and multi-branch tree approach to democracy measurement. Distinguishing between different features and sub-dimensions of democracy, the authors show that only certain features of democracy have a positive impact on climate protection and that the underlying mechanisms are impossible to identify if scholars focus only on highly aggregated democracy scores. Linking this to the trade-off approach developed by Lauth and Schlenkrich (2018), there is clear evidence that scholars should also make use of democracy measures below their highest levels of aggregation.

Moreover, data from different sources can be better compared or combined at lower levels of aggregation. The potential gain is twofold. First, there is an increased awareness of ambiguities implied by differences in concept building and operationalization between measures of democracy. The grand tour of regime classifications provided by Lührmann et al. (2018), for instance, shows in a scrupulously precise way how strongly even minor differences between measures of democracy affect descriptive inference at higher levels of aggregation. Second, the combination of different data sources or types promises to overcome the limitations inherent to each of them. This holds true at all stages of the research process as shown by the contributions of Elff and Ziaja (2018) and Skaaning (2018). Finally, the contributions by Fleuß et al. (2018) as well as Landman (2018) highlight how the application of certain more maximalist definitions of democracy could change the comparison of different democratic regimes significantly.

Without doubt, this thematic issue will not be the final contribution to the vast body of democracy measurement literature and having read this introduction, many will agree that such a convergence is unlikely. Democratic regimes are confronted with new and different developments and challenges, as are the researchers who try to measure the state of such democracies. This is not a problem but rather distinguishes scientific approaches from normative teleology and doomsday rhetoric.

As our look into the history of democracy measurement has shown, these days we are blessed with much more advanced and nuanced measures-in theoretical as well as in methodological terms. These allow us to address both new and old questions which are of relevance for many different research areas. Choice indeed matters! Ongoing debates in democracy measurement, which certainly will be influenced by the contributions to this thematic issue, underline that complacency is not a virtue in academia. Fortunately, this thematic issue reveals that further improvement is not only necessary but also possible.

\section{Acknowledgments}

We would like to thank Daniel Bochsler from the Democracy Barometer project as well as Daniel Kübler from the National Center of Competence in Research (NCCR) Democracy at the University of Zürich for providing the funds to conduct an author workshop in Zürich in May 2017. We also would like to thank Lea Heyne and Yvonne Rosteck for their help in organizing the event. Our thanks go to the German Institute for Global Area Studies (GIGA) for providing additional funds. Moreover, we are indebted to Katarina Pollner who proofread an earlier ver- 
sion of this editorial. Finally, we would like to thank all the authors who contributed to this thematic issue for all their efforts and excellent articles.

\section{Conflict of Interests}

The authors declare no conflict of interests.

\section{References}

Abramowitz, M. J. (2018). Democracy in crisis. Freedom in the world 2018. Washington, DC, and New York, NY: Freedom House.

Adelman, I., \& Morris, C. T. (1971). A conceptualization and analysis of political participation in underdeveloped countries. Part 2 of the final report to the Agency of International Development. Washington, DC: Agency of International Development.

Altman, D., \& Pérez-Liñán, A. (2002). Assessing the quality of democracy: Freedom, competitiveness and participation in eighteen Latin American Countries. Democratization, 9(2), 85-100.

Alvarez, M., Cheibub, J. A., Limongi, F., \& Przeworski, A. (1996). Classifying political regimes. Studies in Comparative International Development, 31(2), 3-36.

Armstrong, D. A. (2009). Measuring the democracyrepression nexus. Electoral Studies, 28(3), 403-412.

Beetham, D. (1994). Key principles and indices for a democratic audit. In D. Beetham (Ed.), Defining and measuring democracy (pp. 25-43). London: Sage Publications.

Beetham, D. (2004). Towards a universal framework for democracy assessment. Democratization, 11(2), 1-17.

Blalock, H. M. (1982). Conceptualization and measurement in the social sciences. Beverly Hills, CA: Sage Publications.

Bochsler, D., \& Kriesi, H. (2013). Varieties of democracy. In H. Kriesi, S. Lavenex, F. Esser, J. Matthes, M. Bühlmann, \& D. Bochsler (Eds.), Democracy in the age of globalization and mediatization (pp. 96-102). Basingstoke: Palgrave Macmillan.

Bogaards, M. (2012). Where to draw the line? From degree to dichotomy in measures of democracy. Democratization, 19(4), 690-712.

Bollen, K. A. (1980). Issues in the comparative measurement of political democracy. American Sociological Review, 45(3), 370-390.

Bollen, K. A. (1991). Political democracy. Conceptual and measurement traps. In A. Inkeles (Ed.), On measuring democracy. Its consequences and concomitants (pp. 3-20). New Brunswick and London: Transaction Publishers.

Bollen, K. A. (1993). Liberal democracy: Validity and method factors in cross-national measures. American Journal of Political Science, 37(4), 1207-1230.

Bollen, K. A., \& Jackman, R. W. (1989). Democracy, stability, and dichotomies. American Sociological Review, $54(4), 612-621$.
Bollen, K. A., \& Paxton, P. (1998). Detection and determinants of bias in subjective measures. American Sociological Review, 63(3), 465-478.

Bollen, K. A., \& Paxton, P. (2000). Subjective measures of liberal democracy. Comparative Political Studies, 33(1), 58-86.

Bühlmann, M., Merkel, W., Müller, L., \& Weßels, B. (2012). The democracy barometer: A new instrument to measure the quality of democracy and its potential for comparative research. European Political Science, 11(4), 519-536.

Casper, G., \& Tufis, C. (2003). Correlation versus interchangeability: The limited robustness of empirical findings on democracy using highly correlated data sets. Political Analysis, 11(2), 196-203.

Cheibub, J. A., Gandhi, J., \& Vreeland, J. R. (2010). Democracy and dictatorship revisited. Public Choice, 143(1), 67-101.

Coleman, J. S. (1960). Conclusion: The political systems of the developing areas. In G. A. Almond \& J. S. Coleman (Eds.), The politics of the developing area (pp. 532-576). Princeton, NJ: Princeton University Press.

Collier, D., \& Adcock, R. (1999). Democracy and dichotomies: A pragmatic approach to choices about concepts. Annual Review of Political Science, 2(1), 537-565.

Coppedge, M., Alvarez, A., \& Maldonado, C. (2008). Two persistent dimensions of democracy: Contestation and inclusiveness. The Journal of Politics, 70(3), 632-647.

Coppedge, M., Gerring, J., Altman, D., Bernhard, M., Fish, S., Hicken, A., . . . Teorell, J. (2011). Conceptualizing and measuring democracy: A new approach. Perspectives on Politics, 9(2), 247-267.

Cutright, P. (1963). National political development: Measurement and analysis. American Sociological Review, 28(2), 253-264.

Cutright, P., \& Wiley, J. A. (1969). Modernization and political representation: 1927-1966. Studies in Comparative International Development, 5(2), 23-44.

Dahl, R. A. (1956). A preface to democratic theory. Chicago, IL, and London: University of Chicago Press.

Dahl, R. A. (1971). Polyarchy: Participation and opposition. New Haven, CT: Yale University Press.

Diamond, L. (2008). The democratic rollback. The resurgence of the predatory state. Foreign Affairs, 87(2), 36-48.

Diamond, L., \& Morlino, L. (2005). Assessing the quality of democracy. Baltimore, MD: The Johns Hopkins University Press.

Downs, A. (1957). An economic theory of democracy. New York, NY: Harper \& Row Publishers.

Elff, M., \& Ziaja, S. (2018). Method factors in democracy indicators. Politics and Governance, 6(1), 92-104.

Elkins, Z. (2000). Gradations of democracy? Empirical tests of alternative conceptualizations. American Journal of Political Science, 44(2), 293-300.

Escher, R., \& Walter-Rogg, M. (2018). Does the concep- 
tualization and measurement of democracy quality matter in comparative climate policy research? Politics and Governance, 6(1), 117-144.

Ferrín, M., \& Kriesi, H. (Eds.). (2016). How Europeans view and evaluate democracy. Oxford: Oxford University Press.

Fishman, R. M. (2016). Rethinking dimensions of democracy for empirical analysis: Authenticity, quality, depth, and consolidation. Annual Review of Political Science, 19(1), 289-309.

Fleuß, D., Helbig, K., \& Schaal, G. S. (2018). Four parameters for measuring democratic deliberation: Theoretical and methodological challenges and how to respond. Politics and Governance, 6(1), 11-21.

Fuchs, D., \& Roller, E. (2018). Conceptualizing and measuring the quality of democracy: The citizens' perspective. Politics and Governance, 6(1), 22-32.

Gasiorowski, M. J. (1990). The political regimes project. Studies in Comparative International Development, 25(1), 109-125.

Gastil, R. D. (1991). The comparative survey of freedom: Experiences and suggestions. In A. Inkeles (Ed.), On measuring democracy. Its consequences and concomitants (pp. 21-46). New Brunswick and London: Transaction Publishers.

Geißel, B., Kneuer, M., \& Lauth, H.-J. (2016). Measuring the quality of democracy: Introduction. International Political Science Review, 37(5), 571-579.

Giebler, H. (2012). Bringing methodology (back) in: Some remarks on contemporary democracy measurements. European Political Science, 11(4), 509-518.

Giebler, H., \& Merkel, W. (2016). Freedom and equality in democracies: Is there a trade-off? International Political Science Review, 37(5), 594-605.

Gleditsch, K. S., \& Ward, M. D. (1997). Double take: A reexamination of democracy and autocracy in modern polities. The Journal of Conflict Resolution, 41(3), 361-383.

Gurr, T. R., Jaggers, K., \& Moore, R. T. (1991). The transformation of the Western state: The growth of democracy, autocracy, and state power since 1800. In A. Inkeles (Ed.), On measuring democracy. Its consequences and concomitants (pp. 69-104). New Brunswick and London: Transaction Publishers.

Held, D. (2010). Models of democracy. Cambridge: Polity Press.

Hill, D. W. (2016). Democracy and the concept of personal integrity rights. The Journal of Politics, 78(3), 822-835.

Hill, D. W., \& Jones, Z. M. (2014). An empirical evaluation of explanations for state repression. American Political Science Review, 108(3), 661-687.

Huntington, S. P. (1991). Democracy's third wave. Journal of Democracy, 2(2), 12-34.

Inglehart, R., \& Welzel, C. (2005). Modernization, cultural change, and democracy. The human development sequence. Cambridge: Cambridge University Press.
Inkeles, A. (Ed.). (1991). On measuring democracy. Its consequences and concomitants. New Brunswick and London: Transaction Publishers.

Jackman, R. W. (1973). On the relation of economic development to democratic performance. American Journal of Political Science, 17(3), 611-621.

Jackman, S. (2008). Measurement. In J. M. BoxSteffensmeier, H. E. Brady, \& D. Collier (Eds.), The Oxford handbook of political methodology (pp. 119-151). Oxford: Oxford University Press.

Johnson, K. F. (1976). Scholarly images of Latin American political democracy in 1975. Latin American Research Review, 11(2), 129-140.

Landman, T. (2012). Assessing the quality of democracy: The international IDEA framework. European Political Science, 11(4), 456-468.

Landman, T. (2018). Democracy and human rights: Concepts, measures, and relationships. Politics and Governance, 6(1), 48-59.

Lauth, H.-J. (2011). Quality criteria for democracy. Why responsiveness is not the key. In G. Erdmann \& M. Kneuer (Eds.), Regression of democracy? Zeitschrift für Vergleichende Politikwissenschaft Comparative Governance and Politics (pp. 59-80). Wiesbaden: VS Verlag für Sozialwissenschaften.

Lauth, H.-J. (2015). The matrix of democracy. A threedimensional approach to measuring the quality of democracy and regime transformations. Würzburg: Universität Würzburg.

Lauth, H.-J., Pickel, G., \& Welzel, C. (2000). Grundfragen, Probleme und Perspektiven der Demokratiemessung [Fundamental questions, problems and perspectives on democracy measurement]. In H.-J. Lauth, G. Pickel, \& C. Welzel (Eds.), Demokratiemessung. Konzepte und Befunde im internationalen Vergleich [Democracy measurement. Concepts and results in comparative perspective] (pp. 7-26). Wiesbaden: VS Verlag für Sozialwissenschaften.

Lauth, H.-J., \& Schlenkrich, O. (2018). Making tradeoffs visible: Theoretical and methodological considerations about the relationship between dimensions and institutions of democracy and empirical findings. Politics and Governance, 6(1), 78-91.

Levitsky, S., \& Way, L. (2015). The myth of democratic regression. Journal of Democracy, 26(1), 45-58.

Lijphart, A. (1999). Patterns of democracy. Government forms and performance in thirty-six countries. New Haven, CT, and London: Yale University Press.

Lipset, S. M. (1959). Some social requisites of democracy: Economic development and political legitimacy. The American Political Science Review, 53(1), 69-105.

Lührmann, A., Tannenberg, M., \& Lindberg, S. I. (2018). Regimes of the world (RoW): Opening new avenues for the comparative study of political regimes. Politics and Governance, 6(1), 60-77.

Mainwaring, S., Brinks, D., \& Pérez-Liñán, A. (2001). Classifying political regimes in Latin. Studies in Comparative International Development, 36(1), 37-65. 
Mayne, Q., \& Geißel, B. (2018). Don't good democracies need "good" citizens? Citizen dispositions and the study of democratic quality. Politics and Governance, 6(1), 33-47.

Mechkova, V., Lührmann, A., \& Lindberg, S. I. (2017). How much democratic backsliding? Journal of Democracy, 28(4), 162-169.

Merkel, W. (2004). Embedded and defective democracies. Democratization, 11(5), 33-58.

Merkel, W. (2010). Are dictatorships returning? Revisiting the 'democratic rollback' hypothesis. Contemporary Politics, 16(1), 17-31.

Munck, G. L. (2009). Measuring democracy. A bridge between scholarship and politics. Baltimore, MD: Johns Hopkins University Press.

Munck, G. L. (2016). What is democracy? A reconceptualization of the quality of democracy. Democratization, 23(1), 1-26.

Munck, G. L., \& Verkuilen, J. (2002). Conceptualizing and measuring democracy: Evaluating alternative indices. Comparative Political Studies, 35(1), 5-34. Neubauer, D. E. (1967). Some conditions of democracy. The American Political Science Review, 61(4), 1002-1009.

Pemstein, D., Meserve, S. A., \& Melton, J. (2010). Democratic compromise: A latent variable analysis of ten measures of regime type. Political Analysis, 18(4), 426-449.

Pharr, S. J., \& Putnam, R. D. (Eds.). (2000). Disaffected democracies: What's troubling the trialateral countries? Princeton, NJ: Princeton University Press.

Pickel, S., Stark, T., \& Breustedt, W. (2015). Assessing the quality of quality measures of democracy: A theoretical framework and its empirical application. European Political Science, 14(4), 496-520.

Przeworski, A. (1999). Minimalist conception of democracy. A defense. In I. Shapiro \& C. Hacker-Cordón (Eds.), Democracy's value (pp. 23-55). Cambridge: Cambridge University Press.

Przeworski, A., Alvarez, M., Cheibub, J. A., \& Limongi, F. (2000). Democracy and development: Material well- being in the world, 1950-1990. Cambridge and New York, NY: Cambridge University Press.

Puddington, A. (2008). Is the tide turning? Journal of Democracy, 19(2), 61-73.

Sartori, G. (1970). Concept misformation in comparative politics. The American Political Science Review, 64(4), 1033-1053.

Schmitter, P. C., \& Karl, T. L. (1991). What democracy is...and is not. Journal of Democracy, 2(3), 75-88.

Schumpeter, J. A. (1950). Capitalism, socialism \& democracy. New York, NY: Harper \& Brothers.

Shapiro, I. (2003). The state of democratic theory. Princeton, NJ: Princeton University Press.

Skaaning, S.-E. (2018). Different types of data and the validity of democracy measures. Politics and Governance, 6(1), 105-116.

Smith, A. K. (1969). Socio-economic development and political democracy: A causal analysis. Midwest Journal of Political Science, 13(1), 95-125.

Sowell, T. (1994). Race and culture. A world view. New York, NY: Basic Books.

Treier, S., \& Jackman, S. (2008). Democracy as a latent variable. American Journal of Political Science, 52(1), 201-217.

Vanhanen, T. (1971). Dependence of power on resources. A comparative study of 114 states in the 1960s (Vol. 1). Jyväskylä: University of Jyväskylä.

Vanhanen, T. (1997). Prospects of democracy. A study of 172 countries. London: Routledge.

Vanhanen, T. (2000). A new dataset for measuring democracy, 1810-1998. Journal of Peace Research, 37(2), 251-265.

Welzel, C., Inglehart, R., \& Kligemann, H.-D. (2003). The theory of human development: A cross-cultural analysis. European Journal of Political Research, 42(3), 341-379.

Wucherpfennig, J., \& Deutsch, F. (2009). Modernization and democracy: Theories and evidence revisited. Living Reviews in Democracy, 1, 1-9.

\section{About the Authors}

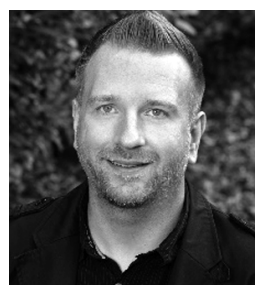

Heiko Giebler is a Senior Researcher at WZB Berlin Social Science Center, Germany. He is also the head of two large-scale projects dealing with the psychological underpinnings of populism and the consequences of populism for democracy. He works on political behavior, populism, democracy measurement, and applied quantitative methodology. Heiko Giebler has published articles in several peerreviewed journals, among others the British Journal of Political Science, German Politics, and Electoral Studies as well as several edited volumes and special issues.

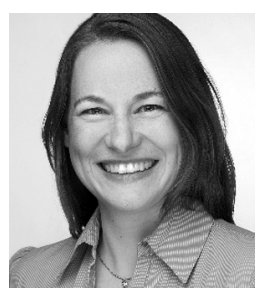

Saskia P. Ruth a Research Fellow at the German Institute of Global and Area Studies in Hamburg, Germany. Her research focuses on the consequences of populism and clientelism for the quality of democratic governance with a special focus on the Latin American region. She has published articles in The Journal of Politics, Latin American Politics and Society, Political Studies, as well as Swiss Political Science Review. 


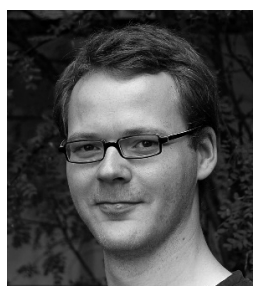

Dag Tanneberg is a Research Fellow at the Chair of Comparative Politics, University of Potsdam, Germany. His research interests span authoritarian rule, contentious politics, state repression, and applied methods in political science. Dag Tanneberg has published in several peer-reviewed journals, among them Politische Vierteljahresschrift, Zeitschrift für Vergleichende Politikwissenschaft, and Contemporary Politics. 